\title{
PERAN GOJEK SEBAGAI AKSES PUBLIK WISATAWAN DI BALI DAN PELOPOR EKONOMI KREATIF
}

\author{
Made Handijaya Dewantara \\ Universitas Prasetiya Mulya \\ Email: made.handijaya@pmbs.ac.id
}

\begin{abstract}
This study aims to understand the position of Gojek as public access to tourists when traveling in Bali, by looking at the positioning strategy of Gojek as an innovative model for online platform in the field of transportation services, as well as one of the alternative solutions for tourism accessibility, which can be beneficial in sustainable tourism in Bali. The research was conducted through in-depth interviews and indepth observation. Through the research conducted, it can be concluded that the Gojek application as an online application based on transportation and public access has a significant role in the tourism industry in Bali. As the first decacorn in Indonesia, Gojek has demonstrated its commitment to fulfill the satisfaction of all the needs and desires of customers with requests that change from time to time, especially for those who have activities in Bali. This was demonstrated through various application variants released by Gojek as a start-up company. By understanding the needs and desires of tourists vacationing in Bali, Gojek can understand the behavior of consumers who use services again continuously which will lead to customer loyalty. Gojek also provides important positioning through their marketing strategies. As a transportation-based application, Gojek also make partners with local entrepreneurs who can generate creativity and a shared economy model. This creation is demonstrated through innovation and creativity and business that provides many job opportunities for Gojek partners. The reliability of Gojek in their marketing strategy is demonstrated through their seven-marketing mix.
\end{abstract}

Keywords: transportation, innovation, creativity, accessibility.

\section{Pendahuluan}

Saat ini transportasi sudah menjadi kebutuhan pokok bagi seluruh lapisan masyarakat. Fungsi transportasi juga memainkan peran penting dalam industri pariwisata, terutama dalam hal memastikan aksesibilitas terbaik bagi wisatawan. Ekonomi masyarakat dan pemerintah akan lebih baik jika memiliki sistem 
transportasi yang baik. Dengan sistem transportasi yang baik, akan memudahkan mobilitas wisatawan dan pengunjung, serta sumber daya pendukung lainnya, sehingga dapat mendukung pertumbuhan ekonomi di masyarakat perkotaan dan pedesaan. Salah satu pilar utama dari industri pariwisata adalah ekonomi kreatif. Oleh karena itu, untuk melaksanakan kegiatan pariwisata pemerintah perlu menyediakan sistem transportasi yang memungkinkan transportasi melalui darat, air, dan udara untuk menjangkau seluruh wilayah Indonesia.

Pengembangan transportasi, sebagai pilar penting dalam aksesibilitas wisatawan, tentu tidak dapat berdiri sendiri dan membutuhkan dukungan dari sektor lain, seperti ekonomi, populasi, dan sosial. Jika peningkatan volume transportasi tidak sebanding dengan pembangunan jalan, hal tersebut dapat menyebabkan kemacetan yang akan memperlambat laju perekonomian (Prawiranata, 2017). Sehingga diperlukan layanan transportasi umum untuk mengurangi jumlah kemacetan. Tingkat kemacetan yang tinggi akan berdampak pada minat wisatawan untuk datang ke tujuan.

Dengan peluang ini, bisnis di sektor transportasi umum di beberapa daerah juga berkembang, seperti taksi, bus perjalanan, dan transportasi umum lainnya. Namun, transportasi-transportasi juga dianggap tidak memadai, dilihat dari kapasitas, layanan, fasilitas di dalamnya, bahkan kemacetan yang telah ditimbulkan (Tumuwe et al., 2018). Posisi angkutan umum di beberapa destinasi wisata kelas dunia sangat vital. Misalnya, tujuan wisata utama di Asia seperti Singapura, Kuala Lumpur, Bangkok, ke tujuan wisata di Eropa seperti Roma, Paris dan Barcelona, memiliki sistem transportasi umum yang memudahkan wisatawan untuk berpindah dari satu tujuan ke yang berikutnya.

Putra (2016) dalam penelitiannya juga menyatakan bahwa, Trans Sarbagita (Denpasar, Badung, Gianyar, Tabanan) yang diyakini sebagai primadona wisatawan serta solusi untuk mengurangi kemacetan di Bali, belum mampu memenuhi 
tuntutan masyarakat, terutama wisatawan yang berlibur di Bali. Selain itu bus sering tidak tepat waktu saat mengangkut penumpang. Masalah lainnya adalah budaya masyarakat yang belum menjadikan transportasi umum menjadi andalan saat bepergian, sehingga tingkat pengisian bus tidak terlalu tinggi. Meskipun tarif yang dibayarkan tergolong sangat rendah, orang lebih suka menggunakan kendaraan pribadi. Demikian pula, wisatawan yang datang ke Bali sering memilih untuk menyewa sepeda motor dan mobil, meskipun tidak banyak dari mereka yang memiliki SIM. Akibatnya, cukup sering dijumpai wisatawan yang mengalami kecelakaan saat mengemudi baik saat mengendarai sepeda motor atau mobil.

Kendaraan pribadi yang paling sering digunakan di Indonesia adalah sepeda motor (Giri dan Dewi, 2017). Lebih terlihat di Bali, di mana wisatawan mengendarai lebih banyak sepeda motor daripada mobil atau bus. Namun, motor juga memiliki fungsi sebagai angkutan umum, karena digunakan untuk mengangkut orang atau barang dengan kecepatan tertentu. Dengan kemajuan teknologi informasi dan komunikasi, saat ini sepeda motor sebagai transportasi umum telah diwujudkan dalam bentuk sepeda motor online, salah satunya adalah Gojek. Gojek adalah aplikasi yang melayani transportasi melalui layanan ojek dan menjadi media penghubung bagi penumpang dan pengemudi (Junior, 2017). PT. Aplikasi Karya Anak Bangsa sebagai perusahaan pemilik Gojek Indonesia didirikan pada 2010 di Jakarta oleh Nadiem Makarim. Junior (2017) juga menyatakan, Gojek memiliki komitmen untuk meningkatkan kesejahteraan sosial dengan menciptakan efisiensi pasar dan menawarkan manfaat besar bagi pelanggan dan penyedia layanan. Seperti yang dinyatakan oleh beberapa wawancara yang dilakukan, ojek online ini sangat membantu dalam hal waktu, ketepatan, keamanan dan biaya. Selain itu, Gojek juga secara tidak langsung membuka peluang bagi pengemudi ojek untuk mendapatkan penghasilan yang lebih baik. Penelitian ini disusun untuk mengetahu sejauh mana peran Gojek dalam akses publik bagi wisatawan di Bali dan sekaligus pelopor ekonomi kreatif bagi masyarakat Bali. 


\section{Tujuan dan Manfaat Penelitian}

Artikel ini disusun berdasarkan studi kualitatif untuk menjawab pertanyaan, bagaimana Gojek sebagai aplikasi taksi motor online dapat berperan sebagai bagian dari aksesibilitas pariwisata di Bali sekaligus sebagai pelopor ekonomi kreatif bagi masyarakat (khususnya pengusaha rintisan) di Bali. Penelitian ini dilakukan dengan tujuan untuk memahami posisi utama dan jenis angkutan umum baru sebagai salah satu solusi alternatif, yang dapat mempromosikan keberlanjutan industri pariwisata di Bali. Di sisi lain, penelitian ini dilaksanakan dalam menjawab peran ganda gojek sebagai pelopor industry kreatif, mulai dari makanan, minuman, kesenian, dan kebudayaan. Penelitian ini memberikan Batasan kepada produk Gojek yang terkait dengan transportasi dan ekonomi kreatif (GoRide, GoCar, GoFood, dan GoMassage), meskipun dalam pembahasannya tidak menutup pada aplikasi lainnya.

Perumusan masalah ini akan dicoba melalui mekanisme penelitian ilmiah dengan melihat fenomena yang terjadi di tengah industri pariwisata di Bali, dengan melihat pada literatur kepustakaan yang terkait. Penelitian ini diharapkan dapat memberikan manfaat praktis sebagai panduan untuk mengimplementasikan transportasi umum untuk industri pariwisata. Di sisi lain, penelitian ini diharapkan dapat memberikan manfaat praktis dalam menumbuhkembangkan industri kreatif antara pengusaha dan platform online berbasis transportasi. Secara teoritis, penelitian ini diharapkan dapat memberikan manfaat bagi teori transportasi, kepustakaan mengenai online platform, pustaka baru berkaitan dengan ekonomi kreaitf, termasuk utamanya dalam perannya dalam pariwisata. 


\section{Metode Penelitian}

Penelitian ini dilakukan selama satu bulan, dengan menggunakan pendekatan data kualitatif. Penelitian ini berlangsung selama dua bulan, dari 1 Maret hingga 1 Mei 2019. Diikuti kemudian dengan analisis data dan penulisan artikel untuk kemudian diajukan ke salah satu jurnal terindeks. Semua pengumpulan data dilakukan di Bali sebagai lokasi penelitian utama dan di Universitas Prasetiya Mulya, BSD sebagai lokasi analisis data. Penelitian ini menggunakan dua jenis teknik pengumpulan data, yaitu wawancara dan observasi yang dilakukan secara mendalam.

Untuk mendapatkan jumlah informan yang tepat, peneliti membagi informan menjadi tiga kategori yaitu mitra Gojek yang bekerja sebagai pengendara sepeda motor, mitra Gojek sebagai pengusaha industri kreatif, dan wisatawan yang menggunakan aplikasi Gojek dalam berwisata. Pengalaman tersebut kemudian ditangkap melalui wawancara dan observasi. Pengalaman tidak terbatas pada wisatawan internasional atau wisatawan domestik yang menggunakan aplikasi untuk membuat jarak jauh, tetapi juga untuk tujuan lain seperti pengiriman makanan dan kegiatan berbelanja. Jumlah informan dibatasi hingga berjumlah 5 orang pada masing-masing kategori dengan mempertimbangkan waktu dan durasi penelitian.

Teknik pengambilan sampel yang digunakan untuk wawancara dan observasi mendalam di sini adalah Snowball sampling. Definisi pengambilan sampel bola salju adalah teknik penentuan sampel yang awalnya kecil, kemudian diperbesar. Seperti bola salju bergulir yang tumbuh besar untuk waktu yang lama, selama hampir dua minggu. Pengambilan data kemudian dihentikan sampai data dianggap jenuh dan dapat menjawab rumusan masalah. 
Setelah semua data dikumpulkan, semua data dianalisis dengan metode deskriptif kualitatif, melalui teori transportasi umum dan kepentingannya untuk kegiatan pariwisata. Teori tentang transportasi umum online juga akan ditambahkan untuk digunakan nanti dalam menjawab pertanyaan dan menarik kesimpulan.

\section{Kajian Pustaka}

Tiga literatur ditinjau untuk menentukan peran penting transportasi umum untuk mendukung aksesibilitas untuk kegiatan pariwisata. Van Truong (2017) menjelaskan pada sebuah artikel dan menyebutkan bahwa mengintegrasikan transportasi, terutama transportasi umum dan pariwisata akan menjadi faktor penting untuk akses yang tepat untuk kegiatan pariwisata dan industry kreatif yang melibatkan masyarakat. Litman (2008) menjelaskan bahwa terdapat 12 faktor transportasi yang mempengaruhi aksesibilitas suatu destinasi sekaligus kemudahan dalam menyelenggarakan industri kreatif, khususnya: (i) transportasi untuk kualitas opsi transportasi, berkenaan dengan kecepatan, kenyamanan, dan keselamatan; (ii) jaringan transportasi untuk meningkatkan keterpaduan perjalanan antar tujuan; (iii) keterjangkauan perjalanan; (iv) kecepatan dan jarak perjalanan, kapasitas, atau waktu perjalanan; (v) integrasi tautan dan moda dalam sistem transportasi; (vi) permintaan transportasi; (vii) ketersediaan informasi yang dapat diandalkan tentang pilihan mobilitas dan aksesibilitas; (viii) pengganti mobilitas; (ix) pengelolaan transportasi; (x) faktor penggunaan lahan; (xi) prioritas kegiatan perjalanan; dan (xii) isolasi. Meningkatkan faktor-faktor aksesibilitas ini dapat berkontribusi pada keberhasilan ekonomi kreatif suatu destinasi wisata (Currie dan Falconer 2014).

Khan (2017) mendeskripsikan bahwa terdapat peran vital dari sektor transportasi yang sangat dibutuhkan untuk mempromosikan sektor pariwisata di seluruh dunia. Meningkatnya kualitas transportasi, terutama yang terkait dengan layanan pariwisata, terutama yang berkaitan dengan komunikasi dan informasi, 
prosedur pemesanan, restoran, akomodasi, dan layanan transportasi terkait memiliki posisi yang sangat vital tidak hanya untuk meningkatkan aksesibilitas tujuan, tetapi juga dapat mempengaruhi preferensi wisatawan, serta membangkitkan gairah industri kreatif bagi masyarakat sekitar. Pernyataan ini didukung oleh penelitian Chen, 2015, yang juga menyatakan bahwa infrastruktur transportasi harus diintegrasikan untuk aksesibilitas destinasi yang lebih baik.

\section{Gojek Sebagai Akses Publik bagi Wisatawan}

Gojek dianggap sebagai solusi untuk masalah transportasi umum yang saat ini tidak dapat sepenuhnya melayani kebutuhan masyarakat. Layanan ini juga jauh lebih murah dibandingkan dengan menyewa pengemudi atau mengisi bahan bakar untuk mobil, terutama yang berkaitan dengan perjalanan wisata. Selain kebutuhan transportasi untuk bepergian dalam hal perjalanan, Gojek juga menyediakan berbagai layanan lain, seperti Go-Ride, Go-Car, Go-Mart, Go-Clean, Go-Box, GoSend, Go-Med, Go -Makan, Go-Massage, dan sebagainya. Setelah Jakarta, Gojek berekspansi ke Bali. Bali menjadi sasaran karena sebagai daerah wisata memiliki peluang besar dalam menarik wisatawan. Dapat dilihat dari jumlah pengemudi Gojek yang meningkat pesat dari Agustus 2016, yang berjumlah 6.500 driver menjadi 8.000 driver pada Oktober 2016 (Giri dan Dewi, 2017). Ini menunjukkan tingkat tinggi pengguna Gojek, sehingga orang tertarik untuk menjadi pengemudi. Beberapa pengemudi Gojek yang diwawancarai ternyata menggunakan aplikasi ini sebagai pekerjaan sampingan. Dari lima informan yang diwawancarai, mereka ratarata bekerja sebagai satpam hotel, pekerja restoran, pekerja toko, hingga pemilik warung makan, dan menggunakan aplikasi Gojek untuk mencari nafkah di waktu luang, atau mempopulerkan bisnis yang mereka miliki sendiri.

Jumlah pengguna Gojek tidak hanya untuk penduduk setempat yang tertarik untuk menjadi pengemudi, tetapi juga jumlah wisatawan yang mengandalkan 
aplikasi ini. Aplikasi utama yang digunakan oleh wisatawan terutama Go-ride, Gomassage, Go-car, dan Go-Med. Pengamatan menunjukkan bahwa wisatawan cenderung tertarik untuk menggunakan aplikasi ini dengan melihat kemampuannya, cepat, ramah seluler, dan opsi fitur yang diberikan. Aplikasi lainnya yang dimiliki Gojek, mendorong munculnya bisnis-bisnis rintisan baru, yang umumnya bergerak di bidang makanan dan minuman. Perusahaan rintisan ini kemudian bermitra dengan Gojek dengan beberapa faktor antara lain: kedekatan dengan pelanggan, kemudahan pembelian, kemudahan pembayaran (melalui aplikasi Go-pay), hingga jaminan adanya pembeli dengan tips-tips penjualan yang disediakan oleh Gojek setiap minggunya. Tips penjualan ini kemudian tercermin dalam bentuk-bentuk promo yang diberikan oleh Gojek.

Melihat peluang besar dalam layanan transportasi online, pesaing bisnis serupa seperti Grab, Uber, dan sebagainya mulai muncul. Di sisi lain, selain selain adanya kompetitor yang masuk dari jenis perusahaan start up sejenis, hingga kini masih ada penolakan dari taksi konvensional untuk taksi online di Bali. Seperti dilansir Radarbali.jawapos.com (2019), karena penolakan taksi online untuk beroperasi di Bali, Gubernur Bali telah menyiapkan aplikasi transportasi online yang khas, disebut aplikasi Bali-Jek yang akan diuji terlebih dahulu. Pratiwi dan Kesumadewi (2017) dalam penelitian mereka juga menyatakan bahwa, pengemudi taksi konvensional menilai orang-orang yang berhak untuk berpartisipasi dalam industri pariwisata di Bali, di mana fasilitas transportasi wisata telah disediakan oleh penduduk di setiap daerah wisata. Hasil observasi menunjukkan bahwa terdapat banyak limitasi daerah serta regulasi yang kurang mendukung inovasi yang diberikan oleh Gojek. Akan tetapi, limitasi tersebut tidak menyurutkan tingkat pertumbuhan bisnis Gojek utamanya dengan mitra-mitra ekonomi kreatif, yang mereka ajak bekerja sama. 
Melihat fenomena ini, posisi Gojek sebagai ojek motor online memang terancam karena persaingan mulai meningkat. Hasil observasi menunjukkan bahwa Gojek sudah mampu bereaksi dan terus berinovasi agar tidak kehilangan pelanggan. Inovasi yang ditunjukkan oleh Gojek terutama pada perannya untuk industri pariwisata di Bali, dapat dilihat pada seberapa hati-hati ini dimulai ketika mereka merilis satu jenis aplikasi ke aplikasi lain. Bentuk-bentuk aplikasi yang mereka tawarkan seperti Go-Pay, Go-Box, dan Go-Send juga memberikan value proposition tersendiri dengan kompetitor transportasi online, ataupun dengan transportasi konvensional lainnya.

Seperti yang dinyatakan oleh Syahbandi (2012), dalam persaingan bisnis, pemasar harus dapat memenuhi semua kebutuhan dan keinginan pelanggan dengan permintaan yang berubah dari waktu ke waktu. Memuaskan kebutuhan dan mendapatkan kepercayaan pelanggan dapat dilakukan dengan memberikan layanan terbaik bagi konsumen. Panjaitan dan Yuliati (2016) dalam penelitian mereka menyatakan bahwa kualitas layanan yang mendapatkan nilai positif dan memiliki kesan yang baik akan meningkatkan kepuasan pelanggan. Dimana faktor-faktor yang paling mempengaruhi kepuasan pelanggan adalah daya tanggap penyedia layanan, diikuti oleh keandalan, jaminan, dan empati (Wijaya, 2017). Gojek telah menunjukkan bahwa mereka dapat memenangkan persaingan besar dalam memulai transportasi, tidak hanya di Indonesia, tetapi juga di negara-negara Asia Tenggara. Gojek mengizinkan pelanggan mereka, untuk memberikan komentar atau sistem penilaian, tidak hanya untuk aplikasi mereka, tetapi juga untuk driver mereka, sebagai mitra. Kesediaan mereka untuk memenuhi dan meningkatkan kepuasan wisatawan diilustrasikan dengan memberikan terjemahan, sehingga batas bahasa dapat diantisipasi. Hal ini semakin menumbuhkan adanya loyalitas dari pelanggan terhadap aplikasi ini. 
Layanan yang dimaksud termasuk mulai dari menawarkan produk jasa, layanan saat memberikan jasa, layanan hingga risiko yang terjadi saat memberikan layanan, dan layanan lainnya (Assauri, 2015). Kepuasan ini dapat dilihat dari perilaku konsumen yang menggunakan layanan lagi secara terus menerus yang akan mengarah pada loyalitas. Namun, sebenarnya apa yang terjadi di Bali saat ini, gojek masih belum mampu menggeser penggunaan kendaraan pribadi dari penghuninya. Pengguna layanan Gojek untuk Go-Ride didominasi oleh wisatawan lokal dan migran. Hal ini dapat disebabkan oleh layanan yang disediakan oleh Gojek yang belum sepenuhnya menarik minat pelanggan untuk menggunakan layanan yang disediakan dan pelanggan tidak terlalu puas dengan layanan yang diberikan. Sehingga pelanggan tidak sepenuhnya percaya untuk menggunakan layanan Gojek terus menerus. Di sisi lain, Gojek mencoba menjawab kepercayaan pelanggan dengan mencoba melakukan penetrasi pada bentuk mitra medianya. Mereka juga turut bekerja sama dengan Bali United sebagai klub sepakbola kebanggaan masyarakat Bali. Bentuk kerjasama ini dilakukan melalui brand activation atau aktivitas-aktivitas lainnya yang melibatkan masyarakat lokal Bali, penggemar Bali United, hingga para wisatawan.

\section{Gojek sebagai Bagian dari Ekonomi Kreatif Kepariwisataan}

Sebagai decacorn pertama di Indonesia, Gojek menyediakan banyak solusi untuk pengguna digital dan seluler di Indonesia. Layanan Gojek, terutama Go-Ride, adalah salah satu pengembangan ekonomi kreatif dan ekonomi bersama, yang berarti bisnis yang mengandalkan inovasi dan kreativitas, dan bisnis yang menyediakan banyak peluang kerja. Namun, di masa depan Go-Ride harus mampu bersaing dengan pesaing sehingga kepuasan pelanggan harus menjadi fondasi utama. Positioning, Go-Ride, atau Gojek dapat dilihat dari studi tentang bauran pemasaran yang dijalankan. Deskripsi dapat dilihat sebagai berikut: 
1. Product. Produk adalah segala sesuatu yang dapat ditawarkan oleh produsen untuk dipertimbangkan, diminta, dicari, dibeli, digunakan, atau dikonsumsi oleh pasar sebagai pemenuhan kebutuhan atau keinginan pasar yang kompetitif, baik dalam bentuk barang dan jasa. Dalam hal ini, yang dianggap sebagai layanan Go-Ride yang ditawarkan oleh Gojek, layanan yang ditawarkan adalah untuk mengantarkan konsumen dari satu tempat ke tempat lain dengan sistem aplikasi. Menurut Kotler (2005: 55), produk / jasa dapat diukur melalui 3 hal, yaitu: variasi, kualitas dan penampilan. Jadi yang dianalisis di sini adalah bagaimana variasi Go-Ride (seperti penentuan jam dan jarak), bagaimana kualitas pengemudi atau pengemudi dan kendaraan serta cara mengendarainya, lalu bagaimana penampilan pengemudi dan kendaraan. Dari sisi kualitas, aplikasi Gojek terus menunjukkan tampilan yang semakin mobile friendly dari hari ke hari, dan semakin mudah dipahami oleh masyarakat luas, tidak hanya orang Bali, bahkan juga oleh turis asing. Dari segi tampilan, tampilan Gojek cukup menarik dan memberikan opsi aplikasi baru berupa Go-Life.

2. Price. Harga sebenarnya sangat relatif dan subjektif dari satu orang ke orang lain. Menurut Chandra (2002) harga dapat diukur termasuk melalui: Harga produk kompetitif, Diskon (diskon), Variasi dalam sistem pembayaran. Jadi, apa yang dianalisis dalam penelitian ini adalah dengan menganalisis kepuasan pelanggan yang disesuaikan dengan perbandingan harga dengan pesaing, memberikan diskon, dan mengevaluasi sistem pembayaran dengan Go-Pay. Hingga saat ini, aplikasi Go-Pay masih memberikan kesempatan memperoleh Cashback bagi para pelanggannya, tidak hanya bagi yang memesan melalui aplikasi Go-Ride atau Go-Food, bahkan juga bagi restoran yang sudah bekerja sama dengan Go-Pay. 
3. Place. Indikator di tempat adalah di mana layanan ini dapat dinikmati oleh konsumen. Karena Go-Ride dapat diakses secara digital dan hampir mencakup wilayah Kota Denpasar dan Kabupaten Badung di Bali, maka penelitian ini memeriksa dalam hal: seberapa puas ketersediaan Go-Ride di berbagai tempat / fasilitas umum, serta seberapa puas aplikasi ini digunakan di beberapa tempat wisata yang dibatasi oleh peraturan adat setempat. Hasilnya, meskipun terdapat limitasi pada aplikasi Gojek pada beberapa tempat desa adat di Bali, mereka masih mampu dapat dijangkau di destinasi-destinasi wisata utama di Bali, seperti Nusa Dua, Kuta, Jimbaran, dan Denpasar.

4. Promotion. Promosi adalah perusahaan bisnis untuk mempengaruhi calon pembeli melalui penggunaan semua elemen dari bauran pemasaran. Media promosi yang dapat digunakan dalam bisnis termasuk periklanan, promosi penjualan, publisitas dan hubungan masyarakat, dan pemasaran langsung. Bentuk promosi Gojek dengan melibatkan warung-warung mitra mereka menunjukkan bahwa bentuk promosi mereka telah berhasil dilakukan dengan melibatkan industri kreatif. Penggunaan baliho dan agen periklanan lainnya juga menunjukkan adanya kolaborasi produktif antara Gojek dengan mitra industri kreatif di Bali. Hingga saat ini, banyak ditemui warung-warung makan tradisional yang mengindikasikan bahwa pemesanan dapat dilakukan melalui aplikasi Gojek.

5. People. Mereka adalah pihak yang memiliki kepentingan dalam menyediakan atau menunjukkan layanan yang diberikan kepada konsumen sebelum, selama dan setelah melakukan transaksi. Jadi dalam aspek ini, yang diteliti adalah bagaimana konsumen puas dengan layanan yang diberikan oleh pengemudi sebelum bepergian, selama perjalanan, dan sesudahnya. Sebagian besar informan mitra Gojek yang diwawancarai 
memiliki indikator 4 bintang lebih pada aplikasinya. Hal ini juga turut didukung adanya loyalitas antara mitra Gojek dengan perusahaan Gojek itu sendiri.

6. Process. Proses tersebut mencakup bagaimana perusahaan melayani permintaan setiap konsumen. Mulai dari pemesanan konsumen hingga akhirnya mereka mendapatkan apa yang mereka inginkan. Studi ini menunjukkan bahwa pelanggan sangat puas dengan proses transaksi melalui aplikasi Gojek ke sistem pembayaran. Proses pelayanan permintaan konsumen semakin baik dengan akurasi pemetaan posisi konsumen maupun posisi tujuan, yang membedakan dengan aplikasi tandingan Gojek lainnya.

7. Physical Evidence. Bagian ini adalah fasilitas pendukung dalam bentuk layanan fisik. Ini termasuk seberapa puas pelanggan Go-Ride untuk mendapatkan fasilitas fisik seperti helm, jaket atau masker pelindung untuk dikendarai, serta seberapa patuh pengemudi untuk menggunakan fasilitas ini. Hasil penelitian menunjukkan bahwa seluruh mitra Gojek telah mengikuti Standard Operational Procedure (SOP) yang telah diberikan oleh perusahaan induk Gojek kepada mereka.

\section{Kesimpulan dan Saran}

Berdasarkan semua temuan dalam artikel ini dapat disimpulkan bahwa aplikasi Gojek sebagai aplikasi online ojek memiliki peran yang sangat penting dalam industri pariwisata di Bali, tidak hanya sebagai akses transportasi publik, melainkan juga menumbuhkan semangat industri ekonomi kreatif. Gojek telah menunjukkan kemampuannya untuk selalu memenuhi dan memenuhi semua kebutuhan dan keinginan pelanggan dengan permintaan yang berubah dari waktu ke waktu. Ini ditunjukkan dari berbagai varian aplikasi yang dirilis oleh Gojek 
sebagai perusahaan pemula. Dengan memahami kebutuhan dan keinginan wisatawan yang berlibur di Bali, Gojek mampu mempelajari dan memahami perilaku konsumen yang menggunakan layanan lagi secara terus menerus yang akan mengarah pada kesetiaan.

Gojek juga memberikan positioning yang penting melalui strategi pemasaran mereka. Sebagai aplikasi taksi motor, permulaan ini menunjukkan jenis bisnis baru berdasarkan kreativitas dan ekonomi berbagi. Jenis bisnis ini bergantung pada inovasi dan kreativitas dan bisnis yang menyediakan banyak peluang kerja. Bagaimana Gojek yang andal dalam strategi pemasaran mereka menunjukkan melalui bauran tujuh pemasaran mereka.

Melalui artikel ini, peneliti ingin mengusulkan beberapa rekomendasi. Pertama-tama, saran ditujukan kepada pemerintah untuk selalu memberikan akses mudah ke inovasi, terutama untuk sepeda motor dalam menanggapi kebutuhan transportasi umum bagi wisatawan. Kedua, saran diberikan kepada industri transportasi umum untuk terus berinovasi dan berpikir kreatif untuk menjawab kebutuhan dan keinginan pasar, dalam hal ini wisatawan. Ketiga, bagi wisatawan, terutama mereka yang berlibur ke Bali, untuk dapat berpartisipasi aktif dalam penggunaan inovasi transportasi umum, dibandingkan dengan menggunakan transportasi pribadi.

\section{Daftar Pustaka}

Assauri, Prof. Dr. Sofjan MBA. 2015. Marketing Management, Jakarta: PT raja Grafindo Persada.

Chandra, G. 2002. Strategy and Marketing Program. Yogyakarta : Andi.

Chen, Zhenhua, and Kingsley E. Haynes. 2015. "Spatial Impact of Transportation Infrastructure: A Spatial Econometric CGE Approach." In Regional Science Matters, edited by Peter Nijkamp, Adam Rose, and Karima Kourtit, 163-86. Springer International Publishing. 
Currie Christine, Peter Falconer. 2014. Maintaining Sustainable Island Destinations in Scotland: The Role of the Transport-tourism Relationship. Journal of Destination Marketing \& Management, TRANSPORT AND DESTINATION MANAGEMENT, 3 (3) (2014), pp. 162-172.

Giri, Putu Citrayani dan Dewi, Made Heny Urmila. 2017. Analisis Faktor-Faktor yang Mempengaruhi Pendapatan Driver GOJEK di Kota Denpasar, Bali. EJurnal Ekonomi Pembangunan Universitas Udayana. Vol. 6. No. 6. 948-975.

Junior, Mega Swastika. 2017. Fungsionalitas Konflik Gojek: Studi Fenomenologi Terhadap Konflik Pengemudi Gojek di Kota Kediri. Jurnal Analisa Sosiologi. Vol. 6. No. 1. 16-32.

Khan, Syen Abdul Rehman; et al. 2017. The impact of air transportation, railways transportation, travel and transport services on international inbound and outbound tourism. Journal of Air Transport Management. Volume 58, January 2017, Pages 135-143

Kotler, P., 2005. Marketing Management $1^{\text {st }}$ Edition (5nd) ed. Jakarta: PT. Prehallindo.

Litman, Todd. 2008. Evaluating Accessibility for Transportation Planning, March. http://trid.trb.org/view.aspx?id=859513.

Panjaitan, Januar Efendi dan Yuliati, Ai Lili. 2016. Pengaruh Kualitas Pelayanan Terhadap Kepuasan Pelanggan Pada JNE Cabang Bandung. Jurnal Manajemen. Vol. 11. No. 2. 265-289.

Pratiwi, A.A. Manik dan Kesumadewi, Putu Diah. 2017. Keberadaan Transportasi Online Dalam Industri Pariwisata Bali. Seminar Nasional Sains dan Teknologi. Denpasar.

Prawiranata, Halim. 2017. Pengaruh Kualitas Sistem Informasi, Harga, dan Kualitas Pelayanan Terhadap Kepuasan Pelanggan Pada Jasa GOJEK di Kota Yogyakarta. Skripsi. Universitas Negeri Yogyakarta: Pendidikan Akuntansi.

Putra, I Gusti Agung Bagus Angga. 2016. Studi Evaluasi Program Bus Trans Sarbagita Pemerintah Provinsi Bali. Kebijakan dan Manajemen Publik. Vol. 4. No. 1. 1-9.

Syahbandi. 2012. Implementasi Green Marketing Melalui Pendekatan Marketing MIX, Demografi Dan Pengetahuan Terhadap Pilihan Konsumen (Studi The Body Shop Pontianak). Jurnal Ekonomi, Bisnis, dan Kewirausahaan. Volume 3 (1). Hal. 68-86.

Tumuwe, Riswanto., dkk., 2018. Pengguna Ojek Online di Kalangan Mahasiswa Universitas SAM Ratulangi Manado. HOLISTIK. No. 21A. 1-19. 
Van Truong, Nguyen; Shimizu, Tetsuo. 2016. The effect of transportation on tourism promotion: Literature review on application of the Computable General Equilibrium (CGE) Model. Transportation Research Procedia Volume 25, 2017, Pages 3096-3115.

Wijaya, Satria. 2017. Analisis Tingkat Kepuasan Mahasiswa Terhadap Pelayanan Bagian Keuangan Dengan Metode Customer Satisfaction Index. Jurnal Ilmiah Rekayasa dan Manajemen Sistem Informasi. Vol. 3. No. 1. 11-17.

\section{Profil Penulis}

Penulis lahir di Singaraja, Bali, 5 Mei 1989, menikah dan dikaruniai 1 putri, dan saat ini menetap di Tangerang Selatan. Selain berprofesi sebagai dosen S1 Pariwisata di Universitas Prasetiya Mulya, dia juga aktif sebagai anggota dari Mata Garuda (MG), sebuah organisasi para penerima beasiswa LPDP. Pernah memperoleh beasiswa studi dari Bourse Gouvernement Francais (beasiswa Pemerintah Perancis), Kementerian Riset dan Pendidikan Tinggi, serta beasiswa LPDP. Pernah ikut serta sebagai pembicara dalam konferensi yang diselenggarakan United Nations (dalam hal ini UNDPI dan UNESCO) di Korea Selatan, Paris, dan Roma. Pernah ikut serta dalam project film dokumenter kepariwisataan bersama Stasiun Televisi Nasional Perancis. Menjadi narasumber di berbagai kegiatan Kemenpar, mengajar dan membimbing mahasiswa di beberapa Perguruan tinggi di Bali dan Jakarta, serta melakukan beberapa penelitian terkait Pariwisata. 